Original Research Paper

\title{
Evaluating the Effects of Climate Change and Variability on Water Resources: A Case Study of the Cheliff Basin in Algeria
}

\author{
${ }^{1}$ Yamina Elmeddahi, ${ }^{2}$ Hacene Mahmoudi, \\ ${ }^{3}$ Abderrahmane Issaadi, ${ }^{4}$ Mattheus F.A. Goosen and ${ }^{5}$ Ragab Ragab \\ ${ }^{I}$ Faculty of Civil Engineering and Architecture, University Hassiba Ben Bouali of Chlef, Chlef and \\ University of Akli Mohand Oulhadj-Bouira, Algeria \\ ${ }^{2}$ Faculty of Technology, University Hassiba Ben Bouali of Chlef, Algeria \\ ${ }^{3}$ University of Sciences and Technology Houari Boumedienne Algiers (USTHB), Algeria \\ ${ }^{4}$ Office of Research and Graduate Studies, Alfaisal University, Riyadh, Saudi Arabia \\ ${ }^{5}$ Centre of Ecology and Hydrology, CEH, Wallingford, OX10 8BB, UK
}

Article history

Received: 17-03-2016

Revised: $12-04-2016$

Accepted: 05-05-2016

Corresponding Author:

Yamina Elmeddahi

Faculty of Civil Engineering

and Architecture, University

Hassiba Ben Bouali of Chlef,

Chlef and University of Akli

Mohand Oulhadj- Bouira,

Algeria

Tel: +213776199530

Email: elmeddahi-a@hotmail.fr

\begin{abstract}
In aim to well understand of the association between climate change, variability and their impact on water resources availability, an analysis was conducted of the trends in rainfall and stream flows across the Cheliff basin in Algeria. Sen's non-parametric estimator of slope was employed to estimate the extent of tendencies, whose statistical significance was measured by the Mann-Kendall (MK) and the Modified Mann-Kendall (MMK) test. Results showed that the annual rainfall had a statistically significant downward trend in the whole basin. The largest downward trend of $-4.58 \mathrm{~mm} \mathrm{y}^{-1}$ was recorded in the south eastern region of the case study area. Significant decline trends in annual stream flows were detected at up to $-1.18 \mathrm{~m}^{3} \mathrm{~s}^{-1} \mathrm{y}^{-1}$. It was concluded that climate change appears to have an adverse effects on the hydrological cycle involving all water resources in the case study area. The reduced precipitation clearly resulted in a downward trend in water inflow as shown by recorded decrease from 1025 to $815 \mathrm{Mm}^{3}$ between 1968-2001 and 2009. The costs of a water shortage can be an impaired the environmental balance which will affect the various human activities especially domestic water supplies and agricultural economy. The results of the current study will help to enhance the management of natural resources in the Cheliff basin.
\end{abstract}

Keywords: Mann-Kendall, Cheliff Basin, Rainfall Trends, Pre-Whitening, Climate Change, Streamflow

\section{Introduction}

Space-time variability in precipitation and stream flows play key roles in water resources management, particularly in regions characterized by arid and semiarid climates. The analysis of trends has been widely used to assess the possible implications of climate change and variability in hydrological temporal series in different world regions (Kundzewicz et al., 2005; Raziei et al., 2014). Yue et al. (2002) have shown, for example, the power of the Mann-Kendall (MK) statistical test to detect changes in hydrological temporal series as, stream flow, temperature and rainfall.
In 2007, the fourth IPCC report indicated that warming of the climate system is unequivocal (IPCC, 2007). Furthermore, precipitation has increased considerably in some areas of America, Europe and Asia (Muttiah and Wurbs, 2002; Solman, 2013) while decreasing in the Mediterranean region, the Sahel, south part of Africa and Southern regions of Asia at the various temporal and spatial scales (Tramblay et al., 2012; Kosanic et al., 2014). Algeria, like Morocco (Bahir et al., 2002) and other Mediterranean countries (Vicente-Serrano, 2006), have suffered from several periods of drought.

In recent years, many studies showed a downward trend in rainfall in most of northwest Africa 
(Goubanova and Li, 2007; Meddi and Hubert, 2003). Located along the Mediterranean Sea in Northern Africa, Algeria in particular has experienced a decrease in average annual precipitation that began around the second half of the 1970s as shown by a study of the Middle Cheliff watershed (Elmeddahi et al., 2014). Reduced rainfall will continue during the coming century (Ragab and Prudhomme, 2002; Giorgi and Lionello, 2008). This is especially noteworthy in semiarid regions. Latest reports have analyzed the modification in rainfall regimes at the global and regional levels over the world. These studies indicate that any analysis of hydro-climatic variables must be done at a local level instead than a large or global level (Sharma and Shakya, 2006; Barua et al., 2013). This is because the trends and their effects can be varying from one area to the other. Nevertheless, the evolutions are not the same for all areas and severity must be evaluated locally for resources management. The economy of Cheliff basin in Algeria for instance depends largely on agricultural and pastoral products. The major factor which limits production of these crops is water from rainfall. This limited water resource also restricts water supply for domestic and industrial use.

Most precipitation studies have focused on the variability of the annual, seasonal or monthly rainfall at a large scale (Meddi and Meddi, 2007), while fewer were devoted to trend precipitation analyses at the local scale (Bakreti et al., 2013), possibly due to insufficient high quality and long records of data. The reduction in rainfall in recent decades in the Cheliff basin resulted the significant drop in water levels in dam reservoirs in particularly in the western and southern regions of study area. This has been accompanied by intense drought. This condition has brought to overexploitation of groundwater, especially for irrigation. Groundwater potential or availability is intimately combined to changes in precipitation; these have also affected the management of these resources which has had negative Implications on the groundwater. However, a study on the trends of flows in the Cheliff basin region has not as yet been carried out.

The Mann-Kendall (MK) non-parametric test has frequently been employed for determining monotonic trends in hydro meteorological and other non-normal distribution series (Hamed, 2008). This test is based on ranks (Helsel and Hirsch, 2002). The importance of detected changes can be achieved at various important significance levels (usually considered at 0.05). The existence of autocorrelation in the analyzed temporal series alters the statistics results obtained by the MK, where as a positive correlation may overestimate the likelihood of detecting a significant tendency and the reverse can result its underestimated.
Variety of methods were suggested in the literature to avoid the problem of the negative effect of autocorrelation on the results of trend tests, such as prewhitening, which is among the most robust methods which alerts errors overview of trends (Kulkarni and Von Storch, 1995; Hamed and Rao, 1998; Khaliq et al., 2009; Hamed, 2009). A suggestion was made in a recent paper that pre-whitening is not advisable if there is a real trend in the data. The magnitude of the trend of this test is estimated by the estimator of the Sen's slope (Sen, 1968).

The purpose of this study was to gain better understanding of the association between climate change, variability and their impact on water resources availability by analyzing the trends in rainfall and stream flows across the Cheliff basin in Algeria. Trend detection analysis has been carried using nonparametric tests. The Mann-Kendall test would confirm that there is a positive or negative trend for a certain confidence level. The magnitude of linear tendency was calculated by using Sen's estimator. The study was performed with monthly and annual rainfall data recorded at 32 stations during an observation period of 38 to 101 years and monthly, seasonal, annual and maximum flow data on 6 gauging stations in the observation period varies from 26 to 46 years. The focus was given to find out whether there was any significant change in the precipitation and streamflow time series records over the years.

\section{Materials and methods}

\section{Description of Study Area}

The Cheliff basin is located in the northwest of Algeria and lies between $34^{\circ}$ and $36^{\circ} \mathrm{N}$ in latitude and between $0^{\circ} 12^{\prime}$ and $3^{\circ} 87^{\prime} \mathrm{E}$ in longitude. The watershed covers an area of $43,750 \mathrm{~km}^{2}$; and is the one of largest basins in the country, being bordered to the north by the coastal-Dahra basin, in the south by the Zahrez basin, in the east by Algiers basin and in the west by the Oran basin. Furthermore, the climate of the case study region is semi-arid Mediterranean with warm summers and cold winters. The Rainfall has a wide interval of variability with a trend of decline from north to south and from east to west. The mean annual rainfall ranges from $300 \mathrm{~mm}$ in the high plains to 600 $\mathrm{mm}$ in the coastal watershed, except in the Zaccar Massif where about $800 \mathrm{~mm}$ have been recorded.

Average annual temperatures decrease gradually from north to south with a minimum registered at Tissemssilt $\left(14.2^{\circ} \mathrm{C}\right)$ and a maximum at Chlef $\left(18.7^{\circ} \mathrm{C}\right)$. Average monthly temperatures follow the same pattern, but the decline is faster in the cold season than in the hot 
season, because of the particularly harsh effect of continentally winter and the regulating influence of the sea in summer. The hot season, months during which average monthly temperatures are higher than the annual average, extends from May to October; while the cold season lasts from November to April. The maximum temperatures of 27 to $28^{\circ} \mathrm{C}$ are reached in August or July and the minimum temperatures are in January and February $\left(3\right.$ to $\left.10^{\circ} \mathrm{C}\right)$.

The Cheliff Wadi is $750 \mathrm{~km}$ long and is the lengthiest 'river' in Algeria. Wadi refers to a dry (short-lived) riverbed that contains water only during periods of heavy rain. The Cheliff Wadi source is in the Saharan Atlas, with $70 \%$ of its annual runoff occurring from December to April. The large variability of hydrological regimes can be observed in the large range of variation of mean annual flow which varies from $0.06 \mathrm{~m}^{3} \mathrm{~s}^{-1}$ to $15.36 \mathrm{~m}^{3} \mathrm{~s}^{-1}$. Extreme values of the flows are of great interest to hydrologists as they constitute a major concern due to their scale, aggressiveness and negative impact on societies and economic and social development. Hydrologic data from three sub-basins of the Cheliff bowl are illustrated in Fig. 1. Monthly rainfall data and monthly flow data over the study area were obtained from the National Meteorological Office (NMO) and the National Agency of Hydraulic Resources (ANRH).

In this study, a total of 23 of hydro climatic variables were selected for study. The stations considered are those with a long series of observation and few gaps. Data of surface water was obtained from the Ministry of Water Resources (MWE) and the groundwater in the Cheliff basin was evaluated under the hydro geological studies conducted by the National Agency of Water Resources.

\section{Methodology}

The non-parametric test of Mann-Kendall (MK) was used for determining monotonic trends in hydro meteorological and other non-normal distribution series (Hirsh et al., 1993; Yue et al., 2002; Hamed, 2008). This test is based on ranks (Helsel and Hirsch, 2002). It measures the degree of significance of the trend at a level of 0.05 .

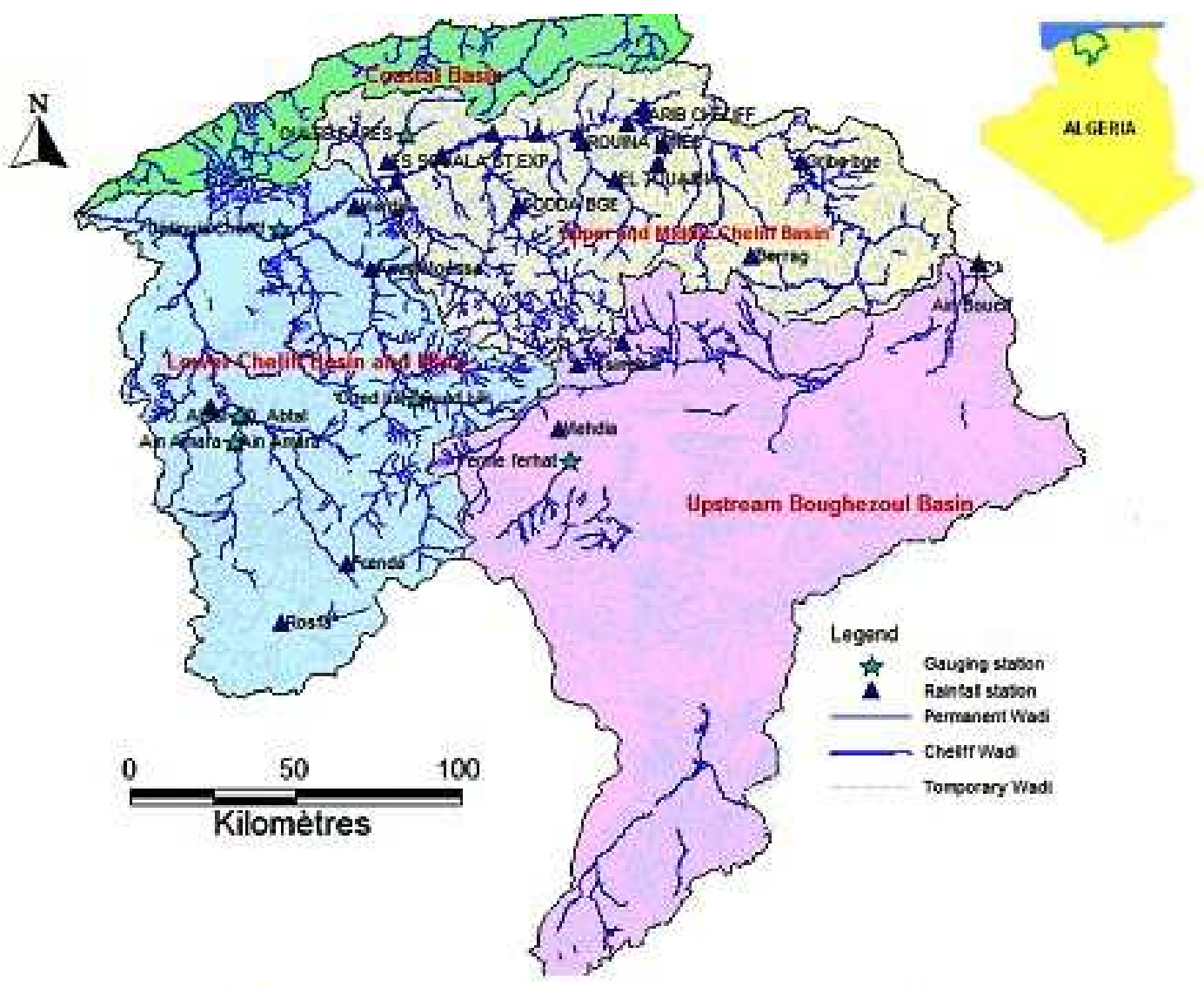

Fig. 1. Location of the study area including the sub-basins 


\section{Autocorrelation}

Before trend analysis, the data correlation structure was checked. The pre-whitening technique was adopted for the serial analysis and to calculate the serial correlation and eliminating it. This approach can be given by the following formula:

$$
Y_{P_{t}}=Y_{t+1}-r Y_{t}
$$

where, $Y_{P_{t}}$ is the pre-whitened value in a time series, $Y_{t}$ is the initial value in a time series for time interval $t$ and $r$ is the estimate serial correlation coefficient.

In this study, a correction for serial dependence by pre-whitening approach was considered when a serial correlation was found to be significant at the $5 \%$ level. The majority of the studied variables showed no significant serial correlation with the exception of annual mean precipitation series at $O$. Sly, Ponteba Bge, Tissemssilt and Khmesti stations. The procedure of prewhitening was made prior to the removing of the autocorrelation from these times series, after that, the trend can be estimated.

\section{Mann-Kendall Test}

The Mann-Kendall statistical test (Mann, 1945; Kendall, 1975) allows for testing of the correlation between the ranks of a time series and their time sequence. Let $\left(x_{1} \ldots x_{n}\right)$ a sample of independent values from a random variable $\mathrm{X}$ of which is to assess the stationarity. The null hypothesis $H_{0}$ is the hypothesis of stationarity of the series (no trend). The alternative hypothesis $H_{1}$ corresponds to the nonstationarity of the series. The Mann-Kendall $S$ statistic is defined as:

$$
S=\sum_{i=1}^{n-1} \sum_{k=i+1}^{n} \operatorname{sgn}\left(X_{k}-X_{i}\right)
$$

Where:

$$
\operatorname{sgn}=\left(X_{k}-X_{i}\right)=\left\{\begin{array}{c}
+1 i f\left(X_{k}-X_{i}\right)>0 \\
0 i f\left(X_{k}-X_{i}\right)=0 \\
-1 i f\left(X_{k}-X_{i}\right)<0
\end{array}\right.
$$

where, $X_{k}$ and $X_{i}$ are of the time series, $n$ is the length of the data sequence. The variance of $S$ and test statistic $Z$ is given by:

$$
\operatorname{Var}(S)=\frac{n(n-1)(2 n+5)-\sum_{i=1}^{m} t_{i}\left(t_{i}-1\right)\left(2 t_{i}+5\right)}{18}
$$

where, $m$ is the number of tied groups and $t_{i}$ is the size of the $i^{\text {th }}$ tied group:

$$
Z=\left\{\begin{array}{l}
\frac{(s-1)}{\sqrt{\operatorname{Var}(s)}} \text { if } S>0 \\
0 \quad \text { if } S=0 \\
\frac{(s-1)}{\sqrt{\operatorname{Var}(s)}} \text { if } S<0
\end{array}\right.
$$

The null hypothesis is accepted or rejected at $\alpha$ depending on whether $\alpha_{1}>\alpha$ or $\alpha_{1}<\alpha$. Generally, the 0.05 level is largely used. In this study, analysis in precipitation variability, 0.05 and 0.01 levels were employed. When the statistical value of $z$ is positive, the trend is increasing and while a negative value indicates a decline trend.

\section{Sen's Median Slope Estimator}

When the hypothesis of no trend is rejected by MannKendall test, the Theil-Sen's Slope (Sen, 1968) allows determining the magnitude of the linear trend. The slope is estimated for $N$ pairs of data points, $Q$, as:

$Q_{i}=\frac{X_{j}-X_{k}}{j-k}$ For $i=1 \ldots \ldots . N$

where, $X_{j}$ and $X_{k}$ are the data values at time $j$ and $k$, respectively, with $j>k$. The median of slope between all pairs of data of $Q$ slope estimates is Sen's linear slope.

\section{Results and Discussion}

The results given by Mann-Kendall and the modified Mann-Kendall tests are presented in Table 2 for rainfall and Table 3 for streamflow. They show the $Z$ statistics estimated for every station for each rainfall and stremaflow variable. The levels of 5 and $10 \%$ were chosen for detecting the significant trend with the superscript indices $a$ and $b$ respectively.

\section{Rainfall Characteristics}

The Chellif watershed is characterized by a decreasing average annual rainfall from north to south, with alterations in the Tellian chains which implies the important role of altitude. Rainfall decreased from 778.8 $\mathrm{mm} \mathrm{y}^{-1}$ in the north to $249.1 \mathrm{~mm} \mathrm{y}^{-1}$ in the south; the latter at a higher altitude. The coefficient of variation of mean annual of precipitations was $30 \%$, which shows a more or less significant variability of the latter.

At the annual scale (Table 1), the spatial variability (represented by the coefficient of variation) from one station to another ranged from 24 to $60 \%$. Spatial variability was compounded by heavy rains which were caused by the Northwest direction winds affecting northwestern regions and the South-West. Changeability was also due to heavy rains in winter and spring that were received by the mountainous parts where the 
altitude exceeds $1000 \mathrm{~m}$ due to the Dahra Mountains compared to the lower plain of Chellif and the western part of the basin (the Wadi Mina basin). The rainfall rarely exceeded $250 \mathrm{~mm} \mathrm{y}^{-1}$ in the Upstream Cheliff Boughzoul. In this region, the semi-arid to arid climate is particularly developed and the effect of latitude is very important. In general, rainfall variability increased as one approaches the arid region and also follows the increase in the longitude and decreasing latitude (Table 1).

The rainfall regime in the Cheliff region has changed from the 1970s. The first rainfall deficit observed in the mid-1970s, continued throughout the 1980s and 1990s (Meddi and Hubert 2003). Based on the study of rainfall variability in the areas of the western Mediterranean (including North Africa) One can say that the mi-1970s and the end of $1980 \mathrm{~s}$, was the most dry period of the century (Knippertz et al., 2003; Valero et al., 2004).This result is coherent with that found in the Cheliff basin. Furthermore, generally, the more humid months are from November to February, while July and August are the driest months. In addition to decreasing annual rainfall, rising temperatures were also observed, with an average increase of $0.9{ }^{\circ} \mathrm{C}$ in Middle Cheliff Basin, for example as shown by Elmeddahi et al. (2014).
The increase in temperature and evapotranspiration combined with reduced rainfall has brought a significant water deficiency with adverse consequences on agricultural production and socio-economic conditions. Studies conducted by the NAHR (1993) have confirmed this negative economic impact because of dry conditions caused by a decrease in inter-annual rainfall.

\section{Seasonal and Annual Trends in Rainfall}

The results of the autocorrelation analysis of the hydro meteorological data revealed that a serial correlation exists in some of time series. However, when the pre-whitening approach was applied, the correlation from these time series is eliminated. In addition, after prewhitening process and MK trend tests for this series, there is a reduced tendency in some of the initial series. The trend analysis effects for annual and seasonal rainfall at all stations are presented in Table 2. The results of the MK and MMK test show a downward trend of annual rainfall in the whole basin. Certain trends are statistically significant. Several of the tendencies are significant at the level of $5 \%$ and two of the trends are significant at the level of $10 \%$. Two of the no significant trends in spring were found to be increasing ( $\mathrm{z}$ - value was $+0.09,+0.66$ at ONM Chlef and O. El Abtal, respectively).

Table 1. Characteristics of the stations in the study area

\begin{tabular}{|c|c|c|c|c|c|c|}
\hline Station & $\begin{array}{l}\text { Years of } \\
\text { record }\end{array}$ & Longitude & Latitude & $\begin{array}{l}\text { Altitude } \\
(\mathrm{m})\end{array}$ & $\begin{array}{l}\text { Mean annual } \\
\text { rainfall (mm/year) }\end{array}$ & $\mathrm{Cv} \%$ \\
\hline ONM Chlef & 75 & $1^{\circ} 20^{\prime} \mathrm{E}$ & $36^{\circ} 12^{\prime} \mathrm{N}$ & 143 & 400.6 & 24.7 \\
\hline Chlef DDA & 43 & $1^{\circ} 36^{\prime} \mathrm{E}$ & $36^{\circ} 19^{\prime} \mathrm{N}$ & 430 & 358.9 & 31.3 \\
\hline ESSOULA & 43 & $1^{\circ} 17^{\prime} \mathrm{E}$ & $36^{\circ} 17^{\prime} \mathrm{N}$ & 110 & 328.9 & 26.1 \\
\hline O.Fares & 43 & $1^{\circ} 24^{\prime} \mathrm{E}$ & $36^{\circ} 24^{\prime} \mathrm{N}$ & 116 & 377.7 & 27.3 \\
\hline PontebaBge & 44 & $1^{\circ} 52^{\prime} \mathrm{E}$ & $36^{\circ} 25^{\prime} \mathrm{N}$ & 140 & 423.0 & 24.4 \\
\hline El Abadia & 43 & $1^{\circ} 68^{\prime} \mathrm{E}$ & $36^{\circ} 25^{\prime} \mathrm{N}$ & 162 & 382.8 & 30.4 \\
\hline Khmesti & 98 & $1^{\circ} 91^{\prime} \mathrm{E}$ & $35^{\circ} 67^{\prime} \mathrm{N}$ & 935 & 444.6 & 47.8 \\
\hline Merdja Amel & 41 & $0^{\circ} 95^{\prime} \mathrm{E}$ & $36^{\circ} 01^{\prime} \mathrm{N}$ & 61 & 288.3 & 34.7 \\
\hline Rouina Mines & 43 & $1^{\circ} 83^{\prime} \mathrm{E}$ & $36^{\circ} 22^{\prime} \mathrm{N}$ & 190 & 506.3 & 27.5 \\
\hline AribEbda & 43 & $2^{\circ} 03^{\prime} \mathrm{E}$ & $36^{\circ} 32^{\prime} \mathrm{N}$ & 280 & 441.0 & 27.3 \\
\hline Harreza & 43 & $2^{\circ} 09^{\prime} \mathrm{E}$ & $36^{\circ} 22^{\prime} \mathrm{N}$ & 312 & 373.9 & 25.2 \\
\hline O. Lili & 38 & $1^{\circ} 26^{\prime} \mathrm{E}$ & $35^{\circ} 52^{\prime} \mathrm{N}$ & 550 & 381.9 & 27.6 \\
\hline El Ababsa & 43 & $2^{\circ} 08^{\prime} \mathrm{E}$ & $36^{\circ} 16^{\prime} \mathrm{N}$ & 320 & 369.9 & 25.5 \\
\hline Ain Defla & 101 & $1^{\circ} 96^{\prime} \mathrm{E}$ & $36^{\circ} 27^{\prime} \mathrm{N}$ & 270 & 491.7 & 25.8 \\
\hline Ain Boucif & 84 & $3^{\circ} 15^{\prime} \mathrm{E}$ & $35^{\circ} 89^{\prime} \mathrm{N}$ & 1250 & 372.5 & 44.5 \\
\hline Ammi Mousa & 90 & $1^{\circ} 12^{\prime} \mathrm{E}$ & $35^{\circ} 88^{\prime} \mathrm{N}$ & 140 & 389.4 & 29.4 \\
\hline Derrag & 93 & $2^{\circ} 39^{\prime} \mathrm{E}$ & $35^{\circ} 91^{\prime} \mathrm{N}$ & 1150 & 578.8 & 30.4 \\
\hline FoddaBge & 68 & $1^{\circ} 61^{\prime} \mathrm{E}$ & $36^{\circ} 24^{\prime} \mathrm{N}$ & 486 & 430.0 & 28.2 \\
\hline Frenda & 75 & $1^{\circ} 03^{\prime} \mathrm{E}$ & $35^{\circ} 07^{\prime} \mathrm{N}$ & 990 & 432.5 & 27.7 \\
\hline GribBge & 66 & $2^{\circ} 56^{\prime} \mathrm{E}$ & $36^{\circ} 17^{\prime} \mathrm{N}$ & 460 & 493.4 & 25.2 \\
\hline Mehdia & 95 & $1^{\circ} 74^{\prime} \mathrm{E}$ & $35^{\circ} 43^{\prime} \mathrm{N}$ & 918 & 389.3 & 26.9 \\
\hline O. Sly & 85 & $1^{\circ} 21^{\prime} \mathrm{E}$ & $36^{\circ} 11^{\prime} \mathrm{N}$ & 95 & 328.9 & 33.9 \\
\hline Rosfa & 54 & $0^{\circ} 81^{\prime} \mathrm{E}$ & $34^{\circ} 90^{\prime} \mathrm{N}$ & 960 & 249.1 & 60.3 \\
\hline O.ElAbtal & 72 & $0^{\circ} 67^{\prime} \mathrm{E}$ & $35^{\circ} 47^{\prime} \mathrm{N}$ & 245 & 432.5 & 27.7 \\
\hline Sidi AEK Djillali & 38 & $0^{\circ} 58^{\prime} \mathrm{E}$ & $35^{\circ} 50^{\prime} \mathrm{N}$ & 225 & 447.0 & 29.2 \\
\hline Ain Amara & 38 & $0^{\circ} 66^{\prime} \mathrm{E}$ & $35^{\circ} 41^{\prime} \mathrm{N}$ & 288 & 275.8 & 31.5 \\
\hline Rouina Mairie & 85 & $1^{\circ} 81^{\prime} \mathrm{E}$ & $36^{\circ} 25^{\prime} \mathrm{N}$ & 190 & 387.6 & 28.5 \\
\hline B.Amir AEK & 85 & $2^{\circ} 27^{\prime} \mathrm{E}$ & $35^{\circ} 87^{\prime} \mathrm{N}$ & 1080 & 475.1 & 28.2 \\
\hline Tissimssilt & 89 & $1^{\circ} 81^{\prime} \mathrm{E}$ & $35^{\circ} 61^{\prime} \mathrm{N}$ & 858 & 405.7 & 28.7 \\
\hline El Touaibia & 43 & $1^{\circ} 93^{\prime} \mathrm{E}$ & $36^{\circ} 12^{\prime} \mathrm{N}$ & 350 & 312.0 & 28.2 \\
\hline KenendaFarm & 79 & $0^{\circ} 81^{\prime} \mathrm{E}$ & $35^{\circ} 67^{\prime} \mathrm{N}$ & 590 & 428.9 & 40.7 \\
\hline
\end{tabular}


Table 2. Mann-Kendall test (MK), Modified Mann-Kendall test (MMK) (statistic z) for mean annual rainfall, winter (DJF) mean rainfall, spring (MAM) rainfall and Sen's slope

\begin{tabular}{|c|c|c|c|c|c|c|}
\hline Station & $\begin{array}{l}\mathrm{MK} \text { and } \mathrm{MMK} \\
\text { Z-Value } \\
\text { (p ann) }\end{array}$ & $\begin{array}{l}\text { Sen.'s slope } \\
(\mathrm{mm} / \text { year })\end{array}$ & $\begin{array}{l}\text { Z-value } \\
\text { (DJF) }\end{array}$ & $\begin{array}{l}\text { Sen.'s Slope } \\
\text { (mm/year) } \\
(\mathrm{DJF})\end{array}$ & $\begin{array}{l}\text { Z-value } \\
\text { (MAM) }\end{array}$ & $\begin{array}{l}\text { Sen.'s Slope } \\
\text { (mm/year) } \\
\text { (MAM) }\end{array}$ \\
\hline ONM Chlef & -1.35 & -0.78 & -1.49 & -0.58 & +0.09 & +0.02 \\
\hline Chlef DDA & -1.08 & -1.88 & -0.87 & -0.95 & -0.72 & -0.48 \\
\hline Essouala & -1.33 & -1.46 & -0.85 & -0.58 & -1.46 & -0.63 \\
\hline O. Fares & -1.50 & -2.86 & -1.37 & -1.39 & $-1.83^{b}$ & -1.30 \\
\hline PontebaBge & -1.60 & -2.64 & -1.60 & -1.40 & -1.57 & -1.20 \\
\hline El Abadia & $-1.79^{b}$ & -2.90 & -0.91 & -0.96 & $-1.96^{\mathrm{b}}$ & -1.34 \\
\hline Khmesti & -1.04 & -0.75 & $-1.78^{b}$ & -0.58 & -1.60 & -0.37 \\
\hline Merdja Amel & -1.57 & -2.20 & $-2.11^{\mathrm{a}}$ & -1.51 & -1.48 & -0.86 \\
\hline Rouina Mines & -1.60 & -1.88 & -1.06 & -0.79 & $-1.98^{\mathrm{a}}$ & -1.11 \\
\hline AribEbda & $-1.77^{\mathrm{b}}$ & -2.98 & -0.70 & -0.90 & $-1.77^{b}$ & -1.51 \\
\hline Harreza & -1.23 & -1.93 & -1.14 & -1.01 & -1.33 & -0.93 \\
\hline O. Lili & $-2.50^{\mathrm{a}}$ & -3.76 & $-2.50^{\mathrm{a}}$ & -2.02 & $-3.36^{\mathrm{a}}$ & -3.34 \\
\hline El Ababsa & -1.37 & -1.64 & -0.95 & -0.91 & -1.64 & -0.88 \\
\hline Ain Defla & $-2.62^{\mathrm{a}}$ & -1.26 & -1.33 & -0.37 & -1.08 & -0.22 \\
\hline Ain Boucif & $-3.76^{\mathrm{a}}$ & -2.97 & $-2.43^{\mathrm{a}}$ & -0.99 & $-3.90^{\mathrm{a}}$ & -1.12 \\
\hline Ammi Mousa & $-2.73^{\mathrm{a}}$ & -1.34 & $-2.25^{\mathrm{a}}$ & -0.61 & -0.85 & -0.20 \\
\hline Derrag & $-2.10^{\mathrm{a}}$ & -1.42 & -1.33 & -0.51 & -0.88 & -0.31 \\
\hline FoddaBge & $-3.40^{\mathrm{a}}$ & -2.65 & $-2.66^{a}$ & -1.10 & -0.95 & -0.34 \\
\hline Frenda & $-2.91^{\mathrm{a}}$ & -1.87 & $-2.58^{\mathrm{a}}$ & -0.91 & $-1.89^{b}$ & -0.31 \\
\hline GribBge & $-3.31^{\mathrm{a}}$ & -2.53 & $-2.24^{\mathrm{a}}$ & -1.21 & $-1.84^{b}$ & -0.93 \\
\hline Mehdia & $-3.81^{\mathrm{a}}$ & -1.95 & $-3.51^{\mathrm{a}}$ & -1.05 & $-2.39^{a}$ & -0.54 \\
\hline O. Sly & $-3.54^{\mathrm{a}}$ & -1.76 & $-2.15^{\mathrm{a}}$ & 0.66 & -1.38 & -0.32 \\
\hline Rosfa & $-3.93^{\mathrm{a}}$ & -3.39 & $-3.14^{\mathrm{a}}$ & -1.56 & $-3.05^{\mathrm{a}}$ & -1.07 \\
\hline O. ElAbtal & $-2.44^{\mathrm{a}}$ & -1.38 & $-4.14^{\mathrm{a}}$ & -1.26 & +0.66 & +0.18 \\
\hline Sidi AEK Djillali & $-3.32^{\mathrm{a}}$ & -2.12 & -0.72 & -0.37 & $-2.76^{\mathrm{a}}$ & -1.23 \\
\hline Ain Amara & $-2.45^{\mathrm{a}}$ & -1.35 & -1.12 & -0.75 & $-3.06^{\mathrm{a}}$ & -1.88 \\
\hline Rouina Mairie & $-2.78^{\mathrm{a}}$ & -1.30 & $-2.06^{\mathrm{a}}$ & -0.61 & -1.21 & -0.26 \\
\hline B.Amir AEK & $-2.72^{\mathrm{a}}$ & -1.55 & -1.03 & -0.43 & -1.40 & -0.46 \\
\hline Tissimssilt & $-1.97^{\mathrm{a}}$ & 0.79 & $-1.72^{b}$ & -0.43 & -0.65 & -0.16 \\
\hline El Touaibia & -1.27 & -1.70 & -0.58 & -0.43 & $-1.75^{\mathrm{b}}$ & -0.88 \\
\hline KenendaFarm & $-5.22^{\mathrm{a}}$ & -4.58 & $-4.77^{\mathrm{a}}$ & -2.18 & $-3.00^{\mathrm{a}}$ & -1.21 \\
\hline
\end{tabular}

${ }^{\mathrm{a}}$ Trend statistically significant at $5 \% ;{ }^{\mathrm{b}}$ Trend statistically significant at $10 \%$

Table 3. Mean annual flow (Mean Q), Mann-Kendall test results (Statistic Z) for mean monthly, mean annual, seasonal streamflow, mean annual maxima streamflow and Sen's slope

\begin{tabular}{|c|c|c|c|c|c|c|c|c|c|c|c|c|c|c|}
\hline Station & $\begin{array}{l}\text { Years of } \\
\text { record }\end{array}$ & $\begin{array}{l}\text { Mean } \\
\mathrm{Q}\left(\mathrm{m}^{3} \mathrm{~s}^{-1}\right)\end{array}$ & Sept. & Oct. & Nov. & Dec. & Jan. & Feb. & Mar. & Apr. & May & Jun. & Jul. & Aug. \\
\hline O. ElAbtal & 46 & 3.67 & $-3.51^{\mathrm{a}}$ & $-2.08^{\mathrm{a}}$ & $-3.53^{\mathrm{a}}$ & $-3.67^{\mathrm{a}}$ & $-3.44^{\mathrm{a}}$ & $-3.34^{\mathrm{a}}$ & $-2.98^{a}$ & $-4.38^{a}$ & $-3.72^{a}$ & $-4.58^{a}$ & $-4.00^{\mathrm{a}}$ & $-4.45^{\mathrm{a}}$ \\
\hline Ain Amara & 34 & 2.90 & -0.64 & +0.70 & $-1.67^{b}$ & $-2.98^{\mathrm{a}}$ & $-2.69^{\mathrm{a}}$ & $-2.65^{\mathrm{a}}$ & $-2.24^{\mathrm{a}}$ & $-3.01^{\mathrm{a}}$ & $-3.63^{a}$ & $-4.18^{a}$ & $-4.43^{\mathrm{a}}$ & $-2.09^{\mathrm{a}}$ \\
\hline O. Lili & 26 & 0.37 & +0.24 & $+2.10^{\mathrm{a}}$ & +1.30 & +0.77 & +0.55 & -0.77 & -1.56 & 0.47 & -0.16 & +0.20 & +1.48 & $+2.69^{\mathrm{a}}$ \\
\hline Ferhat Farm & 26 & 0.06 & -0.79 & -0.10 & -1.23 & -0.49 & $-3.64^{\mathrm{a}}$ & $-2.92^{\mathrm{a}}$ & -1.45 & +0.19 & -0.37 & -1.45 & +0.19 & -0.37 \\
\hline Djidiouia Cheliff & 27 & 15.36 & -0.27 & -1.15 & $-2.85^{\mathrm{a}}$ & $-3.31^{\mathrm{a}}$ & $-2.77^{\mathrm{a}}$ & $-3.34^{\mathrm{a}}$ & $-3.36^{\mathrm{a}}$ & $-3.07^{\mathrm{a}}$ & $-3.35^{\mathrm{a}}$ & $-2.28^{\mathrm{a}}$ & $-1.66^{\mathrm{b}}$ & $-2.73^{\mathrm{a}}$ \\
\hline \multirow[t]{2}{*}{ O. Fares } & 30 & 0.55 & -0.74 & -1.41 & -1.34 & -1.44 & -1.14 & $-1.77^{\mathrm{b}}$ & $-2.48^{\mathrm{a}}$ & $-2.13^{\mathrm{a}}$ & $-2.15^{\mathrm{a}}$ & $-3.49^{\mathrm{a}}$ & $-3.02^{\mathrm{a}}$ & -1.54 \\
\hline & ANN & \multicolumn{2}{|l|}{$\begin{array}{l}\text { Autumn } \\
\text { (Sep-Nov) }\end{array}$} & \multicolumn{2}{|c|}{$\begin{array}{l}\text { Winter } \\
\text { (Dec-Feb) }\end{array}$} & \multicolumn{2}{|c|}{$\begin{array}{l}\text { Spring } \\
\text { (Mar-May) }\end{array}$} & \multicolumn{2}{|c|}{$\begin{array}{l}\text { Summer } \\
\text { (Jun-Aug) }\end{array}$} & \multicolumn{5}{|c|}{$\begin{array}{l}\text { Sen.'sslope } \\
\text { (Qann) } \mathrm{m}^{3} \mathrm{~s}^{-1} / \text { year }\end{array}$} \\
\hline O. El Abtal & $-4.54^{\mathrm{a}}$ & \multicolumn{2}{|l|}{$-2.94^{\mathrm{a}}$} & \multicolumn{2}{|l|}{$-4.34^{\mathrm{a}}$} & \multicolumn{2}{|l|}{$-3.32^{\mathrm{a}}$} & \multicolumn{2}{|l|}{$-4.17^{\mathrm{a}}$} & \multicolumn{5}{|l|}{-0.103} \\
\hline Ain Amara & -0.67 & \multicolumn{2}{|l|}{+0.25} & \multicolumn{2}{|l|}{$-2.92^{\mathrm{a}}$} & \multicolumn{2}{|l|}{$-1.80^{\mathrm{b}}$} & \multicolumn{2}{|l|}{$-3.48^{\mathrm{a}}$} & \multicolumn{5}{|l|}{-0.015} \\
\hline O.Lili & +0.24 & \multicolumn{2}{|l|}{$+3.07^{\mathrm{a}}$} & \multicolumn{2}{|l|}{-0.37} & \multicolumn{2}{|l|}{-0.99} & \multicolumn{2}{|l|}{+0.86} & \multicolumn{5}{|l|}{+0.003} \\
\hline Ferhat Farm & -1.30 & \multicolumn{2}{|l|}{+0.49} & \multicolumn{2}{|l|}{$-3.76^{\mathrm{a}}$} & \multicolumn{2}{|l|}{$-0.02^{\mathrm{a}}$} & \multicolumn{2}{|l|}{-0.02} & \multicolumn{5}{|l|}{-0.002} \\
\hline Djidiouia Cheliff & $-3.61^{\mathrm{a}}$ & \multicolumn{2}{|l|}{$-2.32^{\mathrm{a}}$} & \multicolumn{2}{|l|}{$-3.44^{\mathrm{a}}$} & \multicolumn{2}{|l|}{$-2.98^{\mathrm{a}}$} & \multicolumn{2}{|l|}{$-2.44^{\mathrm{a}}$} & \multicolumn{5}{|l|}{-1.18} \\
\hline O. Fares & $-2.94^{\mathrm{a}}$ & \multicolumn{2}{|l|}{$2.23^{\mathrm{a}}$} & \multicolumn{2}{|l|}{$-2.20^{\mathrm{a}}$} & \multicolumn{2}{|l|}{$-3.02^{\mathrm{a}}$} & \multicolumn{2}{|l|}{$-3.95^{\mathrm{a}}$} & -0.03 & & & & \\
\hline
\end{tabular}

${ }^{\mathrm{a}}$ Trend statistically significant at $5 \% ;{ }^{\mathrm{b}}$ Trend statistically significant at $10 \%$

The value of Sen's slope reflects the change rate being analyzed. The decreasing rate of the annual rainfall ranged from $-0.75 \mathrm{~mm} \mathrm{y}^{-1}$ at Khmesti station to -4.58 $\mathrm{mm} \mathrm{y}^{-1}$ at Kenenda Farm. Significant declining trends were noted in annual average rainfall for Kenenda Farm (z-value at -5.22 and $-4.58 \mathrm{~mm} \mathrm{y}^{-1}$ ) and O.Lili (z- value at -2.50 and $-3.76 \mathrm{~mm} \mathrm{y}^{-1}$ ). The season's rainfall pattern and trends were very similar to the annual ones. 
Significant decreasing trends were observed in seasonal average rainfall in winter for Khmesti (at zvalue -1.78 and $-0.58 \mathrm{~mm} \mathrm{y}^{-1}$ ) and Kenenda Farm(at zvalue -4.77 and $-2.18 \mathrm{~mm} \mathrm{y}^{-1}$ ), in spring, (at $\mathrm{z}$-value 3.36 and $-3.34 \mathrm{~mm} \mathrm{y}^{-1}$ ) at O.Lili.

The significant decreasing trends of average seasonal rainfall had the highest value of decreasing slope (i.e., $3.34 \mathrm{~mm} \mathrm{y}^{-1}$ ) for O Lili in spring (Table 2). However, the results of the two tests (Spearman and MannKendall) applied to yearly rainfall series in Western Algeria, including some stations of our study region, revealed a downward trend in most study sites (Hamlaoui-Moulai et al., 2013). This confirmed the results obtained in the current study. According to the study carried out by Meddi (2013) in North West of Algeria at a large-scale, the results showed a generally downward trend in annual rainfall which is consistent with those obtained in present investigation. Indeed, several studies link the decline in precipitation to the Northern Atlantic Oscillation (NAO) which affected the
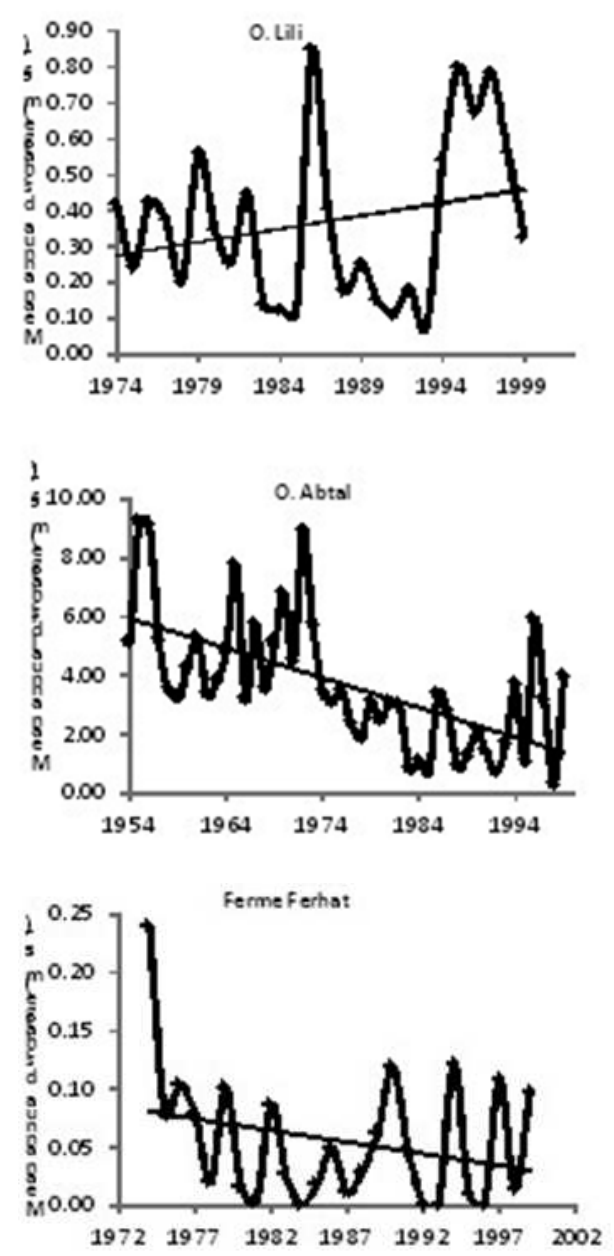

variability of climate index and the hydro climatic variables (e.g., temperature, rainfall, streamflow) in the Mediterranean basin (Rodo et al., 1997), in North Africa (Brandimarte et al., 2011) and in North Algeria, especially of the western region (Meddi et al., 2010).

After the 1970s, rainfall has generally followed a downward trend and lead new water deficit in many zones of the region (Meddi and Talia, 2013). The implications of the deficit can damage environmental equilibrium and thus affect the various human activities which are directly and indirectly related to the use of these resources especially, the severe effects on water supply and agricultural economy. These changes are pushing decision makers to reconsider for crop kinds that can adapt to changed climate conditions in some areas of the country, especially in the study area. But the difficulty in predicting the highly variable seasonal and inter-annual precipitation is an obstacle to decisionmaking advance in water management.
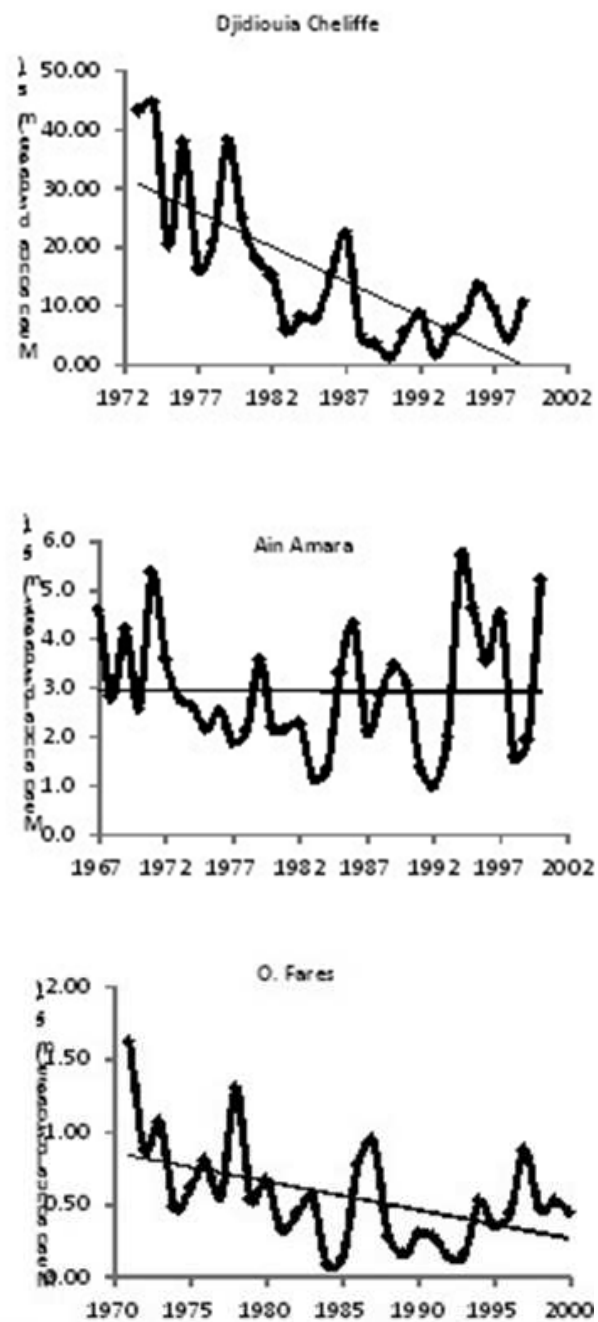

Fig. 2. Linear trend in mean annual streamflow in each gauging stations 


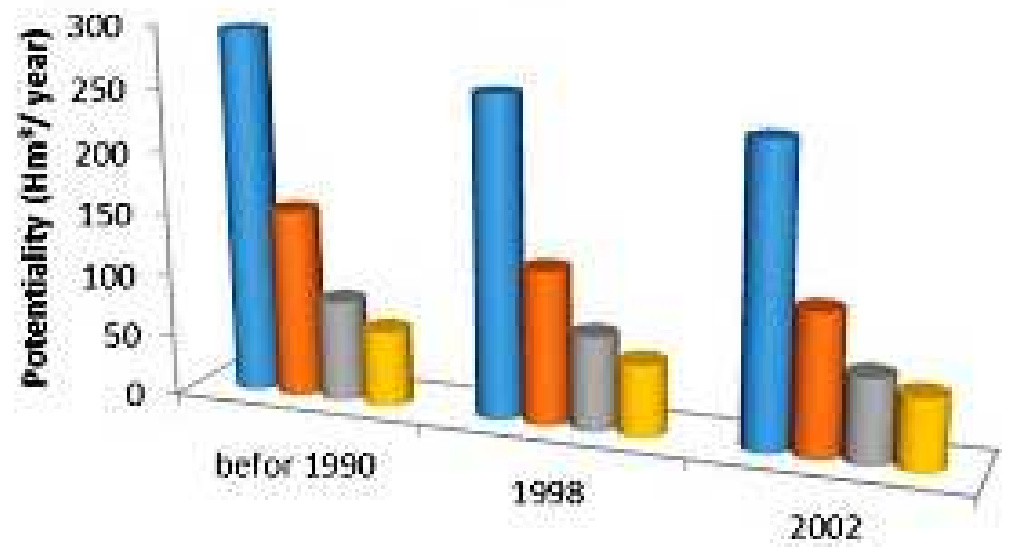

Fig. 3. Progression in groundwater resources potential for Cheliff based and sub-basins (Before 1990, 1998 and 2002)

\section{Monthly, Seasonal and Annual Trends in Stream Flows}

The study of hydrometric series carried out for a long period permit the assessment of the susceptibility of streams to climate change. The inter-annual average flow of the watershed varied between $2.9 \mathrm{~m}^{3} \mathrm{~s}^{-1}$ with a maximum $5.7 \mathrm{~m}^{3} \mathrm{~s}^{-1}$ in 1994 (station of Ain Amara), $3.67 \mathrm{~m}^{3} \mathrm{~s}^{-1}$ with a maximum of $9.25 \mathrm{~m}^{3} \mathrm{~s}^{-1}$ in 1955 (station of O. El Abtal) and $15.36 \mathrm{~m}^{3} \mathrm{~s}^{-1}$ with a maximum of $44.51 \mathrm{~m}^{3} \mathrm{~s}^{-1}$ in 1974 for the Djidiouia Cheliiffe station. For the stations of O. Fares, O. Lili and Ferhat Farm, the values of annual mean flow ranged from $0.55 \mathrm{~m}^{3} \mathrm{~s}^{-1}, 0.37 \mathrm{~m}^{3} \mathrm{~s}^{-1}$ and $0.06 \mathrm{~m}^{3} \mathrm{~s}^{-1}$ with a maximum of $2.37 \mathrm{~m}^{3} \mathrm{~s}^{-1}$ in $2005,0.80 \mathrm{~m}^{3} \mathrm{~s}^{-1}$ in 1995 and $0.24 \mathrm{~m}^{3} \mathrm{~s}^{-1}$ in 1974, respectively (Fig. 2).

The higher flow in the station of Djidiouia Cheliff $\left(15.36 \mathrm{~m}^{3} \mathrm{~s}^{-1}\right)$, due to the positioning of the station on the main river Cheliff which accumulates the flow of other tributaries.

A high variability in monthly and seasonal flows was observed at the most of gauging stations. A significant increasing trend in monthly averages was observed in O. Lili with a $\mathrm{z}$ - value varying from +2.09 to +2.69 in October and August, respectively. A substantial decrease was observed during every month for O. El Abtal, Djidiouia and O. Fares stations and for several months in Ain Amara and Ferhat Farm stations especially during summer.

A substantial seasonal decreasing trend was observed in O. El Abtal station, with maximum z-values of -4.34 in winter (Table 3). The same findings for annual significant trends were seen at $\mathrm{O}$. El Abtal station, with a maximum of -4.54 . The significant decreasing trends of annual flow had the highest value of decreasing slope for Djidiuoia Cheliff, (i.e., $-1.18 \mathrm{~m}^{3} \mathrm{~s}^{-1} \mathrm{y}^{-1}$ ) (Table 3).

A significant increasing trend was observed in O. Lili with a maximum of $z$ - value of +3.07 in autumn. The positive trend in the $\mathrm{O}$. Lili gauging station despite the reduction in rainfall in this region is probably due to the contribution of water released from the Dahmouni dam. Therefore, this result does not suggest any particular regional behavior. Also measurement problems might be responsible for the positive trend. The presence of tendencies in Cheliff stream flow was allocated to declines in precipitation and, to some extent, to increase in temperature.

The current study highlights general irregularities in trends throughout the Cheliff basin. Also, recently and in different catchments in Western Algeria, this tendency of a decline in hydrological regimes features has been confirmed (Meddi and Talia2013). It was noted that the trend of steam flow has never before been documented for the Cheliff basin. In Algeria such as the Cheliff basin, the numbers of gauging stations available that are capable of providing enough abundance of high-quality information to manage water resources are insufficient. For example, in the Cheliff basin with $43,750 \mathrm{~km}^{2}$ out of 43 gauging stations, only 24 hydrometric stations were functioning; so one station for every $1,823 \mathrm{~km}^{2}$.

\section{Impact of Climate Change on Water Resources}

From 1968 to 2001, the interannual inflow of Cheliff basin was estimated at $1,025 \mathrm{M} \mathrm{m}^{3}$, consisting of 687 $\mathrm{Mm}^{3}$ for Middle and Upper Cheliff, $242 \mathrm{Mm}^{3}$ for Lower Cheliff and Mina and $96 \mathrm{Mm}^{3}$ in upstream Bughzoul. In 2009, precipitation decreased to less than $350 \mathrm{~mm}$ and inflow decreased to 815 million $\mathrm{m}^{3}$, 
consisting of $369.6 \mathrm{Mm}^{3}$ (Middle and Upper Cheliff), 392.3 $\mathrm{Mm}^{3}$ (Lower Cheliff and Mina) and $52.83 \mathrm{Mm}^{3}$ in upstream Bughzoul. The decreased precipitation clearly resulted in decreasing trend in water inflow (Meddi and Boucefiane 2013).

One area of concern is that the groundwater potential of the basin which was estimated at $293.98 \mathrm{Mm}^{3} \mathrm{y}^{-1}$ before 1990 decreased to $256.38 \mathrm{Mm}^{3} \mathrm{y}^{-1}$ in 1998 and $237.50 \mathrm{Mm}^{3} \mathrm{y}^{-1}$ in 2002 , which corresponds to a decline of $13 \%$ and $19 \%$ successively (Fig. 3). Given, the effect of climate change on runoff generation in the Cheliff basin, one would expect a decrease in the water supply available for agricultural and domestic use. One can argue that this could also prolong the duration of the dry season in the region that is facing already a sever challenge for water resource allocation.

It was observed that the problem of water scarcity was exacerbated by mismanagement of available water resources and a significant increase in the population that has exceeded 5 million in 2010 (Benblidia and Thivet, 2010). Intensive use for irrigation, adding economic development has put additional pressure on limited water resources. Vital capacities are lost in urban water distribution systems and networks of irrigation are dilapidated or badly maintained. All these failures reflect an inadequate mastery in the management of water resources policy of the country. Better water demand management that would control, reduce and adjust consumption, while avoiding water losses and waste, is imperative (Benblidia and Thivet, 2010).

Faced with these challenges, the country has introduced a new policy to more efficiently manage water resources via, the building new dams, who reached 16 dams with a capacity of 2.205 million $\mathrm{m}^{3}$ according to the Ministry of Water Resources (Elmeddahi et al., 2014). Other projects are in progress (i.e., 5 new dams) which will provide an additional volume of $1608 \mathrm{Mm}^{3} \mathrm{y}^{-1}$ intended for the irrigation and domestic water supply. As well, the use of non-conventional water resources were also dealt by realizes small plants for desalination of sea water in 2001. Two large stations are also ongoing with a production volume estimated as $109.5 \mathrm{Hm}^{3}$. Studies have also been launched on the reuse of treated wastewater for agricultural use.

\section{Conclusion}

This study has shown the importance of identifying local trends that differ from national or global tendencies. The results indicated that for the analyzed time-period, there was a decreasing rainfall in the whole basin, important trends occurring in the west and southeast of the region. Several of the trends are significant at the level of $5 \%$ and two was significant at the $10 \%$ level. Results for annual, mean rainfall revealed a declining trend at most of the stations with the highest value of decreasing slope at $-4.58 \mathrm{~mm} \mathrm{y}^{-1}$ occurring at Kenenda Farm. The mean seasonal rainfall showed similar trends except for two stations; ONM Chlef and O. El Abtal. The climate changes in the last decades will have an adverse effect on water resources, groundwater recharge, filling of reservoir dams and on agricultural yields.

A high variability of monthly and seasonal flow was observed mostly of gauging stations. The important increasing trend was examined in $\mathrm{O}$. Lili with a maximum of $z$ - value ranging +2.69 to +3.07 in August and autumn. The decreasing trends of mean annual flow had the highest value of decreasing slope $-1.18 \mathrm{~m}^{3} \mathrm{~s}^{-1} \mathrm{y}^{-1}$ for Djidiuoia Cheliff.

In closing, climate change in the case study area has had an adverse effect on the precipitation cycle, including all water resources. The reduction in the precipitation clearly produced a downward trend in water inflow as shown by recording annual decreases from 1025 to $815 \mathrm{Mm}^{3}$ between $1968-2001$ and 2009. The consequences of water shortages are changes in the environmental balance which will consequently affect various human activities especially the availability water supply for domestic and industrial consumption as well as for the agricultural economy. It is hoped that the current investigation will help policy makers to make better decisions in developing water management strategies for the watersheds of Algeria.

\section{Acknowledgement}

Authors would like to acknowledge University Hassiba Benbouali of Chlef and the University of Bouira in Algeria for facilities offered for the completion of this research.

\section{Author's Contributions}

Yamina Elmeddahi: Conducted the study in the framework of her $\mathrm{PhD}$ thesis.

Abderrahmane Issaadi: supervised and guided the whole research work.

Mattheus F.A. Goosen, Ragab Ragab and Hacene Mahmoudi: Contributed in substantial revision and improvement of the first draft of the paper and in its final revision.

\section{Ethics}

This article is original and contains unpublished material. The corresponding author confirms that all of the other authors have read and approved the manuscript and no ethical issues involved. 


\section{References}

Bahir, M., A. Mennani, M. Jalal and Y. Fakir, 2002. Impact of drought on water potential of the aquifer supplying drinking water to the city of Essaouira (Mogador, Morocco). Droughts, 13: 13-19.

Bakreti, A., I. Braud, E. Leblois and A. Benali, 2013. Combined rainfall and discharge analysis in the Tafna basin, western Algeria. Hydrol. Sci. J., 58: 133-152. DOI: 10.1080/02626667.2012.745080

Barua, S., N. Muttil, A.W.M. Ng and B.J.C. Perera, 2013. Rainfall trend and its implications for water resource management within the Yarra River catchment, Australia. Hydrol. Processes, 27: 1727-1738. DOI: 10.1002/hyp.9311

Benblidia, M. and G. Thivet, 2010. Water resources management: the limits of a supply-side policy. International Centre for Advanced Mediterranean Agronomic Studies-CIHEAM

Brandimarte, L., G. Di Baldassarre, G. Bruni, P. D’Odorico and A. Montanari, 2011. Relation between the north-atlantic oscillation and hydroclimatic conditions in mediterranean areas. Water Resour. Manage., 25:1269-1279.

DOI: $10.1007 / \mathrm{s} 11269-010-9742-5$

Elmeddahi, Y., A. Issaadi, H. Mahmoudi, M. Tahar Abbes and M.F.A. Goossen, 2014. Effect of climate change on water resources of the Algerian Middle Cheliff basin. Desalinat. Water Treatment, 52: 2073-2081. DOI: 10.1080/19443994.2013.831777

Giorgi, F. and P. Lionello, 2008. Climate change projections for the Mediterranean region. Global Planet. Change, 63: 90-104.

DOI: 10.1016/j.gloplacha.2007.09.005

Goubanova, K. and L. Li, 2007. Extremes in temperature and precipitation around the Mediterranean basin in an ensemble of future climate scenario simulations. Global Planet. Change, 57: 27-42.

DOI: 10.1016/j.gloplacha.2006.11.012

Hamed, K.H. and A.R. Rao, 1998. A modified MannKendall trend test for autocorrelated data. J. Hydrol., 204: 182-196. DOI: 10.1016/S0022-1694(97)00125-X

Hamed, K.H., 2009. Enhancing the effectiveness of prewhitening in trend analysis of hydrologic data. J. Hydrol., 368: 143-155.

DOI: $10.1016 /$ j.jhydrol.2009.01.040

Hamed, K.H., 2008. Trend detection in hydrologic data: The Mann-Kendall trend test under the scaling hypothesis. J. Hydrol., 349: 350-363. DOI: 10.1016/j.jhydrol.2007.11.009

Hamlaoui-Moulai, L., M. Mesbah, D. Souag-Gamane and A. Medjerab, 2013. Detecting hydro-climatic change using spatiotemporal analysis of rainfall time series in Western Algeria. Nat. Hazards, 65: 1293-1311. DOI: 10.1007/s11069-012-0411-2
Helsel, D.R. and R.M. Hirsch, 2002. Statistical methods in water resources techniques of water resources investigations. U.S. Geological Survey.

Hirsch, R.M., D.R. Helsel, T.A. Cohn and E.J. Gilroy, 1993. Statistical analysis of hydrologic data. Handbook Hydrol., 17: 11-55.

IPCC, 2007. The physical science basis, summary for policymakers (contribution of WG I to the 4th Assessment Report of the IPCC). Intergovernmental Panel on Climate Change, Cambridge University Press, Cambridge and New York.

Kendall, M.G., 1975. Rank Correlation Methods. 1st Edn., Charles Griffin, London.

Khaliq, M.N., T.B.M.J. Ouarda, P. Gachon, L. Sushama and A. St-Hilaire, 2009. Identification of hydrological trends in the presence of serial and cross correlations: A review of selected methods and their application to annual flow regimes of Canadian rivers. J. Hydrol., 368: 117-130. DOI: $10.1016 /$ j.jhydrol.2009.01.035

Knippertz, P., M. Christoph and P. Speth, 2003a. Longterm precipitation variability in Morocco and the link to the large-scale circulation in recent and future climates. Meteorol. Atmos. Phys., 83: 67-88. DOI: 10.1007/s00703-002-0561-y

Kosanic, A., S. Harrison, K. Anderson and I. Kavcic, 2014. Present and historical climate variability in South West England. Climatic Change, 124: 221-237. DOI: $10.1007 / \mathrm{s} 10584-014-1101-8$

Kulkarni, A. and V.H. Von Storch, 1995. Monte Carlo experiments on the effect of serial correlation on the Mann-Kendall test of trend. Meteorol. Zeitschrift, 4: 82-85.

Kundzewicz, Z.W., D. Graczyk, T. Maurer, I. Pinskwar and M. Radziejewski et al., 2005. Trend detection in river flow series: 1. Annual maximum flow. Hydrol. Sci. J., 50: 1-810. 10.1623/hysj.2005.50.5.797

Mann, H.B., 1945. Nonparametric tests against trend. Econometrica, 13: 245-259. DOI: 10.2307/1907187

Meddi, M. and P. Hubert, 2003. Impact of changing rainfall patterns on the water resources of northwestern Algeria. Hydrol. Mediterranean Semiarid Regions, 278: 229-235.

Meddi, H. and M. Meddi, 2007. Spatial and temporal variability of rainfall in North West of Algeria. Geographia Tech., 2: 49-55.

Meddi, M.M., A.A. Assani and H. Meddi, 2010. Temporal variability of annual rainfall in the Macta and Tafna catchments, Northwestern Algeria. Water Resource Manage., 24: 3817-3833. DOI: $10.1007 / \mathrm{s} 11269-010-9635-7$

Meddi, M.M. and A. Talia, 2013. Runoff evolution in Macta basin (Northwest of Algeria). Arab. J. Geosci., 6: 35-41. DOI: $10.1007 / \mathrm{s} 12517-011-0318-3$ 
Meddi, M. and A. Boucefiane, 2013. Climate change impact on groundwater in Cheliff-Zahrez basin (Algeria). APCBEE Proc., 5: 446-450.

DOI: $10.1016 /$ j.apcbee.2013.05.077

Muttiah, R.S. and R.A. Wurbs, 2002. Modeling the impacts of climate change on water supply reliabilities. J. Water Int., 27: 407-419. DOI: $10.1080 / 02508060208687020$

NAHR, 1993. Rainfall map of Algeria of North ministry of equipment, Algiers. National Agency of Hydraulic Resources, Algeria

Ragab, R. and C. Prudhomme, 2002. Climate change and water resources management in arid and semi-arid regions: Prospective and challenges for the $21 \mathrm{st}$ Century. Biosyst. Eng., 81: 3-34. DOI: 10.1006/bioe.2001.0013

Raziei, T., J. Daryabari, I. Bordi, R. Modarres and L.S. Pereira, 2014. Spatial patterns and temporal trends of precipitation in Iran. Theor. Applied Climatol., 115: 531-540. DOI: $10.1007 / \mathrm{s} 00704-013-0919-8$

Rodo, X., E. Baert and F.A. Comin, 1997. Variations in seasonal rainfall in Southern Europe during the present century: Relationships with the North Atlantic Oscillation and the El Niño-Southern Oscillation. Clim. Dyn., 13: 275-284.

DOI: $10.1007 / \mathrm{s} 003820050165$

Sen, P.K., 1968. Estimates of the regression coefficient based on Kendall's Tau. J. Am. Stat. Assoc., 63: 1379-1389.

DOI: $10.1080 / 01621459.1968 .10480934$
Sharma, R.H. and N.M. Shakya, 2006. Hydrological changes and its impact on water resources of Bagmati watershed, Nepal. J. Hydrol., 327: 315-322. DOI: 10.1016/j.jhydrol.2005.11.051

Solman, S.A., 2013. Regional climate modeling over South America: A review. Adv. Meteorol., 2013: 504357-504369. DOI: 10.1155/2013/504357

Tramblay, Y., W. Badi, F. Driouech, S. El Adlouni and L. Neppel et al., 2012. Climate change impacts on extreme precipitation in Morocco. Global Planet. Change, 82-83: 104-114. DOI: 10.1016/j.gloplacha.2011.12.002

Valero, F., M.Y. Luma, M.L. Martin and A. Morata, 2004. Coupled modes of large-scale climatic variables and regional precipitation in the western Mediterranean in autumn. Clim. Dyn., 22: 307-323. DOI: $10.1007 / \mathrm{s} 00382-003-0382-9$

Vicente-Serrano, S.M., 2006. Spatial and temporal analysis of droughts in the Iberian Peninsula (19102000). Hydrol. Sci. J., 51: 83 -97. DOI: $10.1623 /$ hysj.51.1.83

Yue, S., P. Pilon and G. Cavadias, 2002. Power of the Mann-Kendall and Spearman's rho tests for detecting monotonic trends in hydrological series. J. Hydrol., 259: 254-271. DOI: $10.1016 / \mathrm{S} 0022-1694(01) 00594-7$ 